\title{
DESCRIPTIVE REVIEW: ABDALLA, M. M., CONEJERO, M. A. \& OLIVEIRA, M. A. (2019). ADMINISTRAÇÃO ESTRATÉGICA: DA TEORIA À PRÁTICA NO BRASIL. SÃO PAULO: ATLAS, 241
}

\author{
(iD) Fernanda Kesrouani Lemos ${ }^{1}$ \\ ${ }^{1}$ Doctor in Business Administration. Universidade Ibirapuera - UNIB. São Paulo, São Paulo - Brasil. \\ fernanda.lemos@ibirapuera.edu.br
}

\begin{abstract}
Objective: Providing readers with a descriptive review, known as a summary of the content of the first edition of the book Strategic Management: from theory to practice in Brazil, to encourage readers to seek the complete work.

Method: Making the summary of the chapters commented out.

Contributions: To develop and expand the understanding of theories, methods of thought in the area of strategic administration, especially in Brazil, to be a guide to the content of the book and to encourage its adoption with institutions that teach the discipline of strategic management, especially to incorporate the Brazilian and Latin American cases into the debates.
\end{abstract}

Keyword: Strategic management. Brazilian cases. Contemporary. Handbook.

RESENHA DESCRITIVA: ABDALLA, M. M., CONEJERO, M. A. \& OLIVEIRA, M. A. (2019). ADMINISTRACÃO ESTRATÉGICA: DA TEORIA À PRÁTICA NO BRASIL. SÃO PAULO: ATLAS, 241

\section{Resumo}

Objetivo: Disponibilizar aos leitores uma resenha descritiva, conhecida como resumo do conteúdo da primeira edição do livro Administração estratégica: da teoria à prática no Brasil, de modo a incentivar os leitores a buscarem a obra completa.

Método: Realização do resumo dos capítulos de forma comentada.

Contribuições: Desenvolver e expandir a compreensão das teorias, métodos linhas de pensamento na área de administração estratégica, em especial no Brasil, ser um guia para o conteúdo do livro e incentivar a adoção do mesmo junto às instituições que lecionam a disciplina de administração estratégica, em especial para que incorporem aos debates os casos brasileiros e latinoamericanos.

Palavras-chave: Administração estratégica. Casos brasileiros. Contemporâneo. Handbook.

REVISIÓN DRESCIPTIVA: ABDALLA, M. M., CONEJERO, M. A. \& OLIVEIRA, M. A. (2019). ADMINISTRAÇÃO ESTRATÉGICA: DA TEORIA À PRÁTICA NO BRASIL. SÃO PAULO: ATLAS, 241

\begin{abstract}
Resumen
Objetivo: Proporcionar a los lectores una revisión descriptiva, conocida como resumen del contenido de la primera edición del libro Gestión estratégica: de la teoría a la práctica en Brasil, con el fin de animar a los lectores a buscar la obra completa.

Método: Elaboración del resumen de los capítulos comentados.

Contribuciones: Desarrollar y expandir la comprensión de teorías, métodos de pensamiento en el área de la administración estratégica, especialmente en Brasil, para ser una guía para el contenido del libro y fomentar su adopción con instituciones que enseñan la disciplina de estrategia. gestión, especialmente para incorporar los casos brasileños y latinoamericanos en los debates.
\end{abstract}

Palabras clave: Gestión estratégica. Casos brasileños. Contemporánea. Manual.

\section{Cite as / Como citar}

American Psychological Association (APA)

Lemos, F. K. (2021). Descriptive review: Abdalla, M. M., Conejero, M. A. \& Oliveira, M. A. (2019). Administração estratégica: da teoria à prática no Brasil. São Paulo: Atlas, 241. Iberoamerican Journal of Strategic Management (IJSM), 20, 1-15,

e19396. https://doi.org/10.5585/riae.v20i1.19396. estratégica: da teoria à prática no Brasil. São Paulo: Atlas, 241. Iberoamerican Journal of Strategic Management (IJSM), v. 20, p. 1-15. 2021. https://doi.org/10.5585/riae.v20i1.19396. 
Strategy studies can be considered new in the area of management professionals currently, strategic management is highly prominent in companies, which enhances its importance in training courses - undergraduate and graduate courses - for professionals able to work in public and private companies. This growth is also evident in the academic world, the representativeness within the largest management association - Academy of Management - draws attention to this fact on a global level. However, it is worth mentioning that this phenomenon is also observed in Brazil.

This phenomenon justifies the expansion of academic and also didactic publications within the scope of the strategy. This book presents the main theories, applications of concepts and brings strategic management in an evolutionary way to its frontier of knowledge. Its structure, divided into three parts, allows the theoretical, frontier approaches to be presented, as well as the structuring beginnings of this theme. This is a differential that keeps the applied contemporaneity that many classic books do not present.

This fact provides a didactic freshness that is added to the presentation of applied cases from Brazil, which adds the constant contrast between the different realities between developed and developing countries to the agenda of the debate. The challenges are different, in many cases directly related to the institutional environment itself, or the innovation networks that are established there. Despite these challenges, many of the companies develop very well designed and successful strategies at the national and international levels.

\section{Purpose of the work}

The book fulfills the purpose of filling some gaps in the strategy area in didactic terms such as the set of approaches presented by it and differentiated structural ordering. It also provides a contrast between the different realities, as it does not stop with cases from developed countries and already considered classics. This combination brings new generations of undergraduate and graduate students to identify with the experienced reality and for researchers and professors the teaching didactics in this thriving reality.

\section{Structure}

The structure divided into three parts marks the beginning of a logical master line that leads to the different strategy approaches presented. The organizers called them: the fundamentals of the strategy, the strategic process and perspectives, and the frontiers of the strategy. The first part consists of three chapters: strategic thinking, competitive positioning, and the resource-based view (RBV). The first chapter fulfills the organizing function of the work and its theoretical bases and what the reader can expect about these three great subdivisions which the book was ordered. The position that Strategic Management is complex and in full development is once, again reinforced by the organizers. 
However, Whittington's observation regarding its depth, relevance and continuous improvement is established by positioning the great didactic classics that fulfilled the ordering role of this literature, such as the "Strategy Safari" by Mintzberg et al. (2000). The work brings the 10 schools that order strategic thinking, even though there is no consensus in terms of acceptance regarding the term "strategic thinking." Richard Whittington systematizes the field of strategy in four major fields: classical, evolutionary, procedural and systemic. The generic denomination emerges from the classification between results (profit maximization x plural) and processes (deliberate $\mathrm{x}$ emergent). Based on the intersection of the axes, the authors synthesize each of the four approaches from the strategic model, its justification, focus, processes, influences keywords, key authors, and period of appearance.

It is observed that by going through such works that are part of such a structure, a historical perspective on the strategy chair is created, which is not always so obvious in textbooks. In some cases, history arises from the systematization of theories visited in general management theory and organizational theory and which are often excluded, as they do not address strategic management objectively. This critical analysis of historical perspective regarding the continuum of the theories of business administration and how they contributed to the strategy chair can be glimpsed and highlighted when analyzing the works of Alfred DuPont Chandler Junior in 1962 and Igor Ansoff in 1965 and his subsequent works. Subsequent chapters 2 and 3, which are part of this first set, talk about strategic positioning and the theory of resource-based vision.

In the first, based on the deduction, the general premises explain the facts that lead to the angulation of the strategy. The second is based on induction and begins with the analysis of the internal environment, and it is possible to arrive at a result from elements that are previously established. This debate leads to the two subsequent chapters, after presenting the reality of research in the field of strategy in Brazil, as an example is the absence of production in public strategy, which is not observed in international publications, but which is part of the Brazilian institutional environment, with massive state and regulatory intervention in the market, an area well explored by economics schools.

The second chapter, Competitive positioning, discusses competitive strategy from the school of strategic positioning. The chapter goes through the concept of market orientation and places it as a facilitator of competitive positioning. It also presents the Diamond model for obtaining competitive advantage, a five-force model for assessing the attractiveness of the industry, generic strategies for competitive positioning, and the value chain for creating and capturing value, all of which are proposed by Michael Porter. The chapter also presents some alternative models to enrich the debate about competitive positioning.

By understanding that the definition of objectives consists of "where" the organization intends to reach, and their strategy is "how-to" or its route, the school of positioning is situated as the link between the organization and the external environment. Igor Ansoff inaugurates this line of thought in 1965 with its matrix that represents four different strategies based on the relationship between product 
and market: market penetration, market development, product development, and diversification, which are strategies portrayed in this book in chapter 6.

Mintzberg et al., (2000) in their work differentiates this school by the following characteristics: its base is in the economic theory of the industrial organization, the formulation of the strategy is an analytical process of the organization towards the environment. The attractiveness of the industry, which is equivalent to the economic sector, can be made from the analysis of the five forces of competitiveness or Porter. The generic strategies of Michael Porter are the basis for formulating the strategy and depend on the analysis of the value chain, the competitive advantage is understood as the differential that the organization creates in relation to its competitors. In this sense, the work of Michael Porter provided a significant contribution to this school with its various models due to stylize and simplify the analysis through models for the world of companies coming from the industrial organization (IO).

When portraying the market as a facilitator for competitive positioning, the authors present the orientation matrix which analyzes what the client values $\mathrm{x}$ how competitors work and then name the different strategic positions that can be: an organization focused on itself - which refers to the classic example of the Ford T; customer orientation; competitor orientation and market orientation. A set of mini-cases is presented to illustrate each of the market guidelines: Nespresso, Basf, and Burger King.

The chapter goes on to introduce the concept of competitive advantage and the diamond model. A country to be competitive in a given sector needs to be substantially productive in its factors of production such as labor and capital. In other words, you need to be able to innovate your products, processes and even the organization. For Porter, the government has a central role in the innovation process, by offering subsidies for it to occur by stimulating 4 factors, which he later called the Diamond Model of Competitive Advantage.

The debate on obtaining and maintaining competitive advantage continues with the presentation of Porter's Five Forces Model, which maintains an intimate relationship between sectoral and economic analysis to provide an analysis of the attractiveness of the industry in which the organization is inserted. The mini-case of fuel retailing is explored as an oligopoly in which $75 \%$ of the market share belongs to four brands and the remaining 25\% to another 200 distributors. The chapter also addresses Porter's generic strategies in which competitive advantage and scope are crossed to delimit between cost leadership, differentiation, focus on costs, focus on differentiation. The distinction between the key strategic elements of each is emphasized, as well as the resources and organizational needs to develop such strategies (Grant, 2016). The mini case of GOL X LATAM, expressively present in the Brazilian commercial airline market, characterizes this block of the chapter emphasizing the differences between the companies and promoting the debate about AZUL's entry into the market and what is its strategy.

It is worth mentioning that although Porter delimits its competitive position in its generic strategies, the competitive advantage of an organization can also emerge from its internal environment, 
which is discussed in the third chapter, a resource-based view, which is complementary to this. In turn, the authors do not fail to address the value already emphasized by Porter in terms of the value chain, its flow of activities and the links between them. The value disciplines and the Delta Model are presented as evolutions of Porter's generic strategies. Treacy and Wiersema (1995) suggest three strategic orientations grouped between product leadership, intimacy with the consumer, and operational excellence. There is an implicit question of planning and control in the organization's production chain, which are very well exemplified by the agribusinesses Terra Santa Agro and Brasil Agro, which have formed organizations in Brazil in the last decades with operational excellence.

As for the strategic orientation of intimacy with the customer, it is worth emphasizing that it is not only the best product on the market but the best package - product + service delivered to a certain group of customers. An example is the heavy machinery industry Caterpillar adopts the position of intimacy with the customer. In addition to their heavy machinery, they developed CAT boots, initially aimed at serving B2B customers. Currently, they are seen in shoe stores and recognized by customers who are looking for sturdy shoes, with protection and style.

The Delta Model, proposed by Hax and Wilde (2001), emerged from the analysis of 100 organizations and workshops with 30 CEOs from globalized organizations. The model advances through a proposal that combines the issue of networks of relationships and strategic alliances, not addressed in the generic strategies model, whose focus is the product. Chapter 2 ends with the case of the negotiation of the purchase of The Body Shop by Natura and the retail sales strategy, which focuses on the analysis of the companies' positioning before the purchase, the role of Natura's consultant in its positioning, and how this changes with the purchase of The Body Shop. The proposal to work with multiple sales channels is proposed for group debate and under what motivations and adaptations.

The third chapter deals with the resource-based view (RBV). This theory proposes that rare, strategic resources are valuable and difficult to imitate, substitute. It also works with capacities as complex groups of skills and knowledge accumulated in the coordination process of the organization and its assets. The combination of these two - resources and capabilities - is called essential competencies that enable the organization to deliver a greater benefit to the consumer. In addition to presenting such concepts, which have been extensively worked on since the 1980s in empirical research in the line of strategic management, the chapter also presents how to assess internal capabilities, which are the dynamic capabilities and the VRIO model.

Classifying resources among financial, physical, legal, human, organizational, informational, and relational (Rossi, 2008) is the first step towards development, protection, and competitive leverage. True capacity emerges with the ability to combine them to generate comparative advantages that demand a superior organization, in other words, generates a distinct offer and difficult to be imitated by competitors. The set of distinct capacities formed by an organization will be the basis for the formation of its essential competencies, once the resources are identified and combined. The authors exemplify how Brazilian companies developed strategic capabilities at different levels: Embraer 
(development of innovative products), Netshoes (reduction of time to Market), Casas Bahia (more efficient distribution and retail channels), Caixa Econômica Federal (brand recall), and the clothing brand Reserva (long-term loyalty).

Day (1994) classifies capabilities by focal point: inside-out processes such as financial management, costs, human resources, environmental sustainability, technology development, integrated logistics, transformation, and manufacturing processes; outside-in processes - market monitoring, connection with the end customer, relationship with distribution channels and traceability; and integrative processes that involve customer service, pricing of products and services, purchasing, delivery, development of new products and services and strategies. This section of the chapter ends with the identification of the capacities that Brazilian beef slaughterhouses need to meet in order to export to the European Union.

Dynamic capabilities pose a challenge to the resource-based view. In highly dynamic contexts, an organization needs to be able to reinvent itself in terms of its resources and capabilities to sustain its competitive advantage. An organization is able to adapt, take advantage of external information and absorb it, transform it and recreate it concurrently, so that it can anticipate the actions of its competitors and protect its intellectual property. The third chapter ends with the VRIO model, which aims to identify the issue of value, rarity, possibility of imitation and exploitation of this resource by the organization. These characteristics define the competitive implications in terms of advantages or unsustainability for an organization, as well as its possibility of economic performance. The case study of the Gerdau group and its family business longevity is presented to debate the organizational aspects that have led to the company's sustainability for more than 100 years and the development of its internal culture based on family values.

The second part of the book, called strategic process, consists of 5 chapters: preliminary definitions of strategic planning, strategic analysis, strategic choice, execution of the strategy description, execution of the strategy related to the measurement and management of the strategy. The first chapter of this block, fourth in general, presents the preliminary definitions of strategic planning: purpose, mission, vision, values, and the formulation of strategic organizational guidelines. This chapter also has a synergistic sense with the first three presented in the first part, which introduces the concepts of strategic thinking, but in addition, all the strategic environmental and industry analysis are made explicit through the main models presented.

In this way, chapter four can be considered a continuity chapter which is understood that after macro and microanalysis, strategic planning can be developed. It is a means to achieve the results that the company wants to obtain and it is necessary to define guidelines and help to identify opportunities, to carry them out in a systematic way to achieve its objectives. To fulfill the purpose of this chapter, the author organizes it into sections with the fundamental components of the strategic formulation: organizational purpose, organizational mission, organizational vision, organizational values, organizational culture. 
In each of these sections, in addition to the fundamental definitions, the author works with reflections from the organizational world, whether in the form of questions that lead to the formulation of a purpose, for example, or motivators that crystallize the reason why strategists should spend time in carrying out these planning steps. As in the other chapters, examples of Brazilian companies such as Magazine Luiza and Bradesco are used.

The values are presented as what provides direction to the behavior, its formation begins with the birth of the organization and they are generally similar to the individual values of its founder or company partners, being consolidated over time. Two examples of transfers of personal values to organizational ones are discussed in the mini-case of Grupo Pão de Açúcar and Abílio Dinis and Commander Rolim Amaro and TAM. Organizational culture, on the other hand, is presented as a silent language, as people connect with the culture and respond to it automatically. It consists of several components such as values, practices, rituals, heroes, and symbols. The case of Banco Real and ABN AMRO is presented as a success, as the culture of Banco Real facilitated the integration process that was necessary after the acquisition.

The fifth chapter, named "Strategic analysis", discusses which is the most appropriate strategy for the company. Different models are presented: Business Model Canvas, B2B and B2C market segmentation, BCG matrix and the product life cycle, SWOT analysis, environment analysis, benchmarking, and internal analysis. The chapter's authors transformed each of these analyzes into a section, where they explore the concepts and provide examples. The first one presents the Canvas Business Model and how it is able to present all 9 key elements that allow the capture of value and obtaining competitive advantage. The model is illustrated with Mercado Livre's case, in which the nine elements are listed and explained. However, the Canvas model is not unique, other models such as RCOV and Abell's three-dimensional model are also explored in the chapter.

The segregation between the types of business to business (B2B) or business to consumer (B2C) customer is presented as a way of positioning, in the following section, as well as the characterization of a product and its life cycle. Known as the BCG Matrix (Boston Consulting Group), the result of a quantitative graphic development to analyze the market growth rate and the relative market share. Its objective is to assist decision-making in the management of the product or business portfolio and the life cycle of each of them. The life cycle of a product is characterized by the phases of introduction, growth, maturity and decline.

Depending on the stage the product is in, its growth rate and the growth of this market, it will be positioned in a different quadrant of the BCG matrix: star, dairy cow, pineapple and interrogation. The interesting thing about the BCG matrix is that although it was designed to analyze products, it extrapolates this universe to analyze markets, businesses. Another relevant aspect is its scope of analysis, that is, it can be applied to different types of businesses and products.

Just as the BCG Matrix is related to the analysis of products, the SWOT Analysis is with the analysis of the scenario in which the company is inserted. The analysis can be considered a portrait of 
the current state of the company and its external environment, when it is crossed or called a crossed SWOT, delimits the strategy to be adopted where there is greater preponderance: offensive strategy, minimization of weaknesses, investment plan alternative sources and survival plan. Thus, the SWOT analysis has a guiding factor regarding the company's strategy in the graphic composition itself that results from it, which will directly imply the choice and execution of the strategy, the subject of the next chapters.

Sections 5.6 to 5.8 bring fundamental elements to arrive at the SWOT analysis, composed of the analysis of the external and internal environment and the stakeholders involved. The PEST analysis is used to check strategic risk and check the political-legal, economic, social, technological and environmental environments. Chapter 5 ends with the case study of Nubank, a fintech in the financial segment that goes against the usual practices of banks that involve not only fees, tariffs, but mainly bureaucracy. The authors propose an analysis of the business model through Canvas and list issues related to the internal and external environment and its multiple analyzes for the design of the strategy.

Chapter six presents a set of theories whose objective is to show the continuity or options for growth, the evolution of organizations maintaining their structure or transforming themselves to expand their markets, product portfolio, billing and profitability. Among the theories, vertical integration, mergers and acquisitions, strategic alliances, organization in clusters, local arrangements and the internationalization process stand out.

The objective of vertical integration is to increase the control and power of a company over the chain in which it operates since it represents the purchase of suppliers or buyers. This type of strategy results from the search for economies of scale, scope and minimization of transaction costs. Mergers and acquisitions, on the other hand, are a movement to consolidate a certain sector of the economy, such as the beverage segment, according to the example book. Such movements aim at operational synergies in production, marketing, product portfolio management and logistics. Also, this is a strategic move for companies to enter international markets, as they already acquire knowledge about the country as a result. The emblematic case of the Itaú and Unibanco banks and their "marriage" of values necessary for the fusion to be feasible is presented in the mini case of the section that still presents the Sadia and Perdigão case that became BR Foods after over 2 years of discussion in the Administrative Council for Economic Defense (CADE) for its approval in defense of competition.

Strategic alliances or joint ventures are also considered part of strategies for entering an internationalization process, although the author has worked on this topic in a specific section. This is because, when entering a new market, this strategy may be less costly for this market to be known. They constitute a commitment between two or more partners who wish to achieve a common goal through the union of resources and capabilities, coordination of activities and sharing of risk. The author illustrates the section with the debate on the mini case of the strategic alliance between Shell and Cosan in the biofuels market that resulted in the creation of Raízen. 
The network approach, clusters or local productive arrangements presupposes the interdependence of companies and the complementarity of capacities and resources. When inserting themselves into a cluster, companies become actors in a virtuous cycle that includes specialized suppliers, qualification and research and the possibility of taking advantage of infrastructure and proximity to public institutions. This environment provides companies with higher productivity than those outside of it, as well as being more competitive in terms of input costs and a greater flow of information through there. The local productive arrangements (LPA) are highlighted as a synonym for clusters, and have the objective of a productive specialty, as is the case of coffee in the cerrado region of Minas Gerais, a mini case of this section. In these arrangements are present companies that are geographically concentrated, various actors such as government organizations, associations and service providers, generation of tacit knowledge and interactive learning between the actors, innovation and governance exercised by businessmen, unions and local associations.

Internationalizing a company is not a routine process, it is related to factors of production, demand conditions, the existence of related and support industries in a given region and the market structure and rivalry between companies for this process to occur or, the way it can happen. The various schools or theories of internationalization support the delimitation if this process occurs in stages, starting with exports first and evolving according to the product cycle (Vernon, 1966), based on Williamson's Transaction Cost Economics (1985) and vertical integration, establishment of joint ventures depending on the type of contract, resources and capacities to be shared, as well as the Uppsala School (Johanson \& Vahlne, 1977, 2009) and Dunning Theory (Dunning, 1993), considered multi-theoretical.

At the frontier of knowledge about internationalization, studies of companies start their international processes between 2 and 15 years after their foundation. Silicon Valley companies are well-known examples around the world. In Brazil, CT\&I, a Brazilian software company and corporate portals, went international to the United States, England, Canada, China and Japan. This mini case is presented at the close of the section. The chapter ends with the case of Braskem and the Brazilian Odebrecht in a historic sequence of strategic expansion actions, directing the debate to the key points and sections of the chapter.

Chapters 7 and 8 refer to the execution of the strategy. Chapter 7 deals with the question of the description of the strategy and its "withdrawal from the plan" to reality. The seminal works of Organization oriented to the strategy, by Kaplan and Norton (2001), and Execution, by Bossidy and Charan (2003), are the basis of the chapter. In both cases there is an addressing of the failures in the execution of the strategy and in its subsequent works. Translating the strategy into operational terms is the first principle of the strategy-oriented organization. The introduction of the Balanced Scorecard (BSC) or balanced performance indicators as a methodology fulfills the role of measuring and managing performance and executing the strategy. The discussion on the use of a simplified or more robust strategic map of the Premier Hospital closes the chapter. 
Chapter 8 can be seen as a continuation of the precedent, it presents the principles of strategyoriented organizations in its sections. It starts with BSC and continues with the organization's alignment with the strategy. This means that the areas of the organization need to work in a connected and coordinated way, which results in strategic maps for the functional and operational areas, consequently a BSC for each of them with assigned indicators and targets. Making strategy a task for everyone, codifies the third principle and in this sense, the efficient communication of the strategy. Recommendations and communication strategies from different authors are presented in the chapter, as well as their platforms.

Kaplan and Norton (2005) postulated that companies that successfully implemented their BSC create a support area called strategy management to transform the strategy into an ongoing process the fourth principle. Its responsibility is to ensure the application of the five principles in daily practices. The last and fifth principles work on the involvement of the leadership in the mobilization of this process since structural changes begin at the top of the organization that presents the infusion of a sense of urgency, the formation of a guiding coalition and the very development of a vision and a strategy. In this way, leadership represents $70 \%$ of the behavioral change process, which is decisive for the execution of the strategy. The chapter is closed by Yellow's case study, shared bikes and scooters and promotes a debate around the challenges of executing its strategy, mapping the reactions of competitors and proposing a timetable and reviewing this company's strategy.

The last part of the book begins with chapter 9 - Strategy as practice - which brings a view of strategy based on routine, which the interactions between different organizational levels, people, internal political games are what characterize this view called strategizing. In this sense, the strategy is created by people, the human factor is the creator of the strategy and the practitioner. Unlike the other theoretical contributions that the book presents and even others in the area of organizational strategy, strategy as a practice does not present itself as a new theory, only as a change of focus. Its entire process and interactions are presented and described. The case of Seguridad is presented for debate in order to contrast the different approaches.

In this micro-organizational perspective, three elements that stand out in the studies from this perspective are also listed: sociomateriality, the middle manager as a practitioner and the subjective elements sensemaking, sensegiving and sensebreaking. The concept of open strategizing and the mini case of Cacau Show show how making strategy in a more participatory way and with multiple sources of information can provide a greater commitment to strategy and decision making. The chapter ends with the Brazilian case of Mormaii.

The second chapter of this block is chapter 10 , which introduces sustainability as a strategic paradigm capable of redirecting the corporate vision and consequently the business strategies. The change in perspective of the external environment brought the importance of sustainability policies for companies, such as including in their strategic core, controlling, governing. Private engagement, especially in developing countries like Brazil, is important because public policies are not sufficient 
to determine a state of national well-being with certain environmental, social, and economic issues that make up the so-called triple bottom line.

In this way, multiple stakeholders have been involved in achieving the Sustainable Development Goals (SDGs), established by the United Nations (UN, 2021), which shows their intention to promote sustainable development in the country. The chapter presents several mini structured cases on the actions of these companies, which places corporate sustainability as a strategic theme.

Moving from a conventional capitalist paradigm to a sustainable one, based on the three pillars of the triple bottom line - planet, people and profit, involves changes regarding the increasingly conscious and demanding consumer market, the incorporation of social and environmental values and not only the economic, greater transparency of actions on the community that is inserted, the establishment of partnerships that generate value for society. This takes into account the construction of a world that is future generations-proof and having corporate governance capable of internalizing the demands of different stakeholders.

The authors present that from a corporate perspective, environmental management occurs at three levels: pollution control of its waste (compliance), prevention - the company starts to have cleaner processes, instead of polluting and cleaning the company, it does not pollute and, finally, the product life cycle analysis, when the company starts to worry about its product from its conception to its disposal. The process is related to reverse logistics, national solid policy and shared responsibility with the population and the good use of its products.

As for social responsibility in corporate environments (CSR), Carrol (1991) described it as a pyramid of four dimensions: i) the company's economic responsibility to society to generate profits; ii) legal responsibility to follow the rules of the country where it is located, which reflects in the codified ethics; iii) local ethical responsibility, which means meeting the ethical norms and standards of consumers, employees, shareholders and the community, following the standards of respect and moral protection of stakeholders; iv) discretionary responsibility - a company engaging in acts or programs aimed at human well-being or goodwill.

Named as creating value for the company through its products and services, the competitive advantage emerges from cost reduction, increased productivity and the generation of value products from the perspective of the sustainability tripod - environmental, social and economic. Governance in the field of sustainability, on the other hand, is concerned with the transparency with which companies are managed regarding their sense of ecological and social citizenship. Governance is seen as a set of complementary mechanisms aimed at protecting investors' rights and reducing administrative opportunism.

However, good corporate governance precepts do not automatically align the demands for sustainability and responsibility, it is necessary that the interests of stakeholders and their demands are also coordinated. Kirin's case shows how the adequacy of its governance to sustainability practices can 
contribute to imbue the company in this paradigm and facilitate the company's interaction with its stakeholders. This chapter ends with a case study on sustainability in the paper industry in Brazil and the importance of investments in sustainable innovations for the company's strategy.

Strategy economics, chapter 11, discusses which governance structure is effective for a company. The chapter retrieves several economic theories that support the organizational strategy, especially those based on criticism of neoclassical theory, to explain this process. Understanding the institutions, the rules of the game and how they impact organizational, political, economic and social actions is part of the scope of the New Institutional Theory and it is the institutions that determine the rules of competition and their effective conditions. In this sense, competition is less a result of the action of companies and more of institutional contexts and efforts to be modified. Thus, the microeconomic aspects considered relevant are: the way in which transactions are organized, their costs and how this impacts on their organizational arrangements; technology is not the central aspect of the firm's organization, although it is very important; the focus is on market failures, highlighting the different institutional forms that vary between market (buy), contractual cooperation (ally) or hierarchy (do).

The Transaction Cost Theory is presented and is at the heart of this debate. By bringing together several concepts such as limited rationality, opportunism, distinction of production costs $\mathrm{x}$ transaction costs, adverse selection, moral hazard, the chapter is dense, the theoretical conceptual complexity is observed. The strategic decision to buy, make or ally depends on this complex analysis that involves the organizational and also the sectorial context, which once again elucidates the importance of the elements presented in previous chapters, as well as the understanding of the characteristics of the transactions. The process of internalizing activities is what culminates in the decision between the governance structures and this may change over time as the strategy's implementation evolves or there is still some market shock. The literature on this topic is extensive and the chapter only brings the first steps towards an understanding of the main concepts, especially as it is considered an emerging approach. However, the literature is widely debated and used for organizational studies and understanding of sectoral developments worldwide. This perspective shows its relevance and also the perspective of evolution in Brazilian cases. The chapter ends with the Myshoes case study that instigates thinking about the company's future expansion decisions in the light of this theory, as well as instigating how it can contribute to the internationalization process.

The business strategy presents a context that is often neglected because it is not marketing and involves government stakeholders, activist groups, citizens, non-governmental organizations (NGOs), in addition to other actors. The study in business administration of these strategic relationships is the theme of chapter 12, called Corporate Political Activity (CPA). The chapter fundamentally presents how companies exercise influence over the government in different ways, legislative and regulatory processes motivated by purposes that may aim to promote the interests of society, but that are more related to corporate interests. The mini case of Vale and the indigenous peoples illustrates how interests 
are divergent between the two sides and propose an integrative debate for students, as well as the types of losses that can occur if Vale takes any wrong action.

The practice occurs as a cyclical activity, as it requires the constant adaptive movement of both sides involved. It can be exercised individually or by interest groups. The chapter presents different views between countries, development contexts and how this activity takes place. Following a theoretical-historical panorama between 1993 and 2017, the authors developed an analytical framework on this topic that involves different strategies, their tactical practices that involve everything from information, financial incentives and the construction of constituencies. The case "Brazil and the rules for the use of pesticides", a socially known debate, opens the debate for students to discuss the framework and its definitions, proposed, and CPA in Brazil. The framework developed by the authors can be considered an advance for the literature and the understanding of this activity in companies, which causes controversy among corporate practices.

\section{Discussion}

When analyzing the content of this work in relation to the repertoire of other business strategy books available for the Brazilian market, it is possible to verify the existence of 4 clusters: translated foreign books; translated foreign books that bring Brazilian cases, contextualizing the country's reality; handbooks and books written by Brazilian authors prioritizing cases applied to the national context. Being differentiated in relation to the context and presentation format of its contents, different audiences of the strategic administration are served.

In the first two groups are the works of foreign authors that have been translated into Portuguese. They bring to our language classic books, some of which have already been mentioned in this article, but which are not applied to the Brazilian reality, or do not yet contemplate the paradigms and frontiers of strategic management within the arrangement of literature. An example in this category is the book by Barney \& Hesterly (2007), which was translated into Portuguese and includes Brazilian case studies provided by the Escola Superior de Propaganda e Marketing (ESPM).

Handbooks tend to present the content in a more schematic and direct way. Managers can have them as a guide in their work environment, which justifies their denomination. Oliveira's book "Estratégia Empresarial \& Vantagem Competitiva" (Business Strategy \& Competitive Advantage) (2014) is an excellent example of this group. The book "Gestão Estratégica" (Strategic Management), by Serra et al. (2014), is very similar to the work under discussion. The authors bring a didactic proposal for the content of strategic management and Brazilian case studies, bringing the content of the book closer to the reality of students, whether they are undergraduate or graduate students. Even so, there is a differential of the work in focus in relation to that of Serra et al. (2014), which is the content called Part III, which brings the scientific frontier of strategic management with current topics such as corporate sustainability, the economics of transaction costs and corporate political activity. 


\section{Conclusion}

The book represents a work on a strategy that goes beyond bringing together the main theories that business students or related areas need to understand. It overflows with the Brazilianness that it brings with it when showing its applicability in the Brazilian reality, which is not commonly found in textbooks. It also exceeds expectations by bringing contemporary theories and paradigms to light in the classroom. In particular, the last chapters are not presented in the context of strategy in many textbooks but are part of individual disciplines due to their relevance. By coordinating these themes with the strategy, the book fulfills a mission of approximating the reality of contemporary students and providing the understanding, connection of such themes in spheres of decision-making.

\section{References}

Ansoff, I. (1965). Corporate Strategy: an analytic approach to business policy for growth and expansion. McGraw-Hill.

Barney, J. B., \& Hesterly, W. S. (2007). Administração estratégica e vantagem competitiva (M. Rosemberg, Trans.). Pearson.

Bossidy, L., \& Charan, R. (2003). Desafio: fazer acontecer: a disciplina de execução nos negócios. Elsevier.

Carroll, A. B. (1991). The pyramid of corporate social responsibility: toward the moral management of organizational stakeholders. Business Horizons, 34(4), 39-48. https://doi.org/10.1016/00076813(91)90005-G.

Chandler, A. D. (1962). Strategy and structure: chapters in the history of American enterprise. MIT Press.

Day, G. S. (1994). The capabilities of market-driven organizations. Journal of Marketing, 58(4), $37-$ 52. https://doi.org/10.2307/1251915.

Dunning, J. H. (1993). Multinational Enterprises and Global Economy. Addison-Wesley.

Grant, R. M. (2016). Contemporary strategy analysis: text and cases edition. Wiley.

Hax, A., \& Wilde II, D. (2001). The Delta project: discovering new sources of profitability in a networked economy. Springer.

Johanson, J. \& Vahlne, J. E. (1977). The internationalization process of the firm: a model of knowledge development and increasing foreign market commitment. Journal of International Business Studies, 8(1) 23-32. https://doi.org/10.1057/palgrave.jibs.8490676.

Johanson, J. \& Vahlne, J.E. (2009). The Uppsala internationalization process model revisited: from liability of foreingness to liability of outsidership. Journal of International Business Studies, 40, 1411-1431. https://doi.org/10.1057/jibs.2009.24.

Kaplan, R. S., \& Norton, D. P. (2001). Organização orientada para a estratégia. Elsevier. 
Kaplan, R. S., Norton, D. P. (2005). The office of strategy management. Strategic Finance, 87(4), 860 .

Mintzberg, H., Ahlstrand, B., \& Lampel, J. (2000). Safári de estratégia. Bookman.

Organização das Nações Unidas (2021). Objetivos de desenvolvimento sustentável (ODS). https://odsbrasil.gov.br.

Oliveira, D. P. R (2014). Estratégia Empresarial \& Vantagem Competitiva: como estabelecer, implementar e avaliar (9th ed.). Atlas.

Porter, M. E. (1980). Competitive Strategy. Free Press.

Porter, M. E. (1986). Estratégia competitiva: técnica para análise de indústrias e da concorrência. Campos.

Rossi, R. M. (2008). Método de análise interna das organizações: uma abordagem a partir da Resource-Advantage Theory [Doctoral Dissertation, Universidade Federal de São Carlos].

Serra, F. R., Ferreira, M. P., Torres, \& A. P., \& Torres, M.C. (2014). Gestão Estratégica: conceitos e casos. Atlas.

Whittngton, R. (2004). O que é estratégia. Thomson.

Williamson, O. E. (1985). The Economic Institutions of Capitalism: Firms, Markets, Relational contracting. The Free Press.

Treacy, M., \& Wiersema, F. (1995). A disciplina dos líderes de mercado: escolha os seus clientes, concentre os seus esforços, domine o seu mercado. Rocco.

Vernon, R. (1966). International investment and international trade in the product cycle. The Quarterly Journal of Economics, 80(2), 190-207. https://doi.org/10.2307/1880689. 